\title{
УДК 616-057+677.51:001.5
}

\section{ЧИ Е НЕБЕ尹ПЕЧНИМИ ШТУЧНІ ЗАМІННИКИ АВБЕСТУ? (ог^яА ヘітератури)}

\section{П'ятниия-Горпинченко Н.К.}

\author{
Інститут меАишини праші АМН України, М. Київ
}

Стрімкий розвиток сучасних технологій виробництва призводить до виникнення якісно нових типів продукції, в тому числі і штучних мінеральних волокон із заданими властивостями. Доведено, що вплив штучних мінеральних волокон може зумовити виникнення таких захворювань, як плевральні бляшки, дифузні плевральні потовщення, легеневий фіброз, рак легень, мезотеліома плеври та очеревини. Необхідно констатувати, що існуючі результати експериментальних та епідеміологічних досліджень не дають змогу зробити остаточний висновок щодо повної безпечності штучних мінеральних волокон для здоров'я людини, багато питань залишаються суперечливими та невирішеними, як то: класифікація штучних мінеральних волокон залежно від фізико-хімічних властивостей, визначення порогів шкідливого впливу, тому подальше дослідження біологічної дії штучних мінеральних волокон та їх внеску у розвиток професійної патології $є$ однією з нагальних проблем сьогодення.

Ключові слова: штучні мінеральні волокна, азбест, біоперсистенція, рівні професійного впливу, поріг шкідливого впливу

Незважаючи на численні дослідження впливу на здоров'я людини різних типів штучних мінеральних волокон, питання щодо потенційного шкідливого впливу цих волокон та їх безпечного промислового використання залишається дискутабельним.

Сучасне виробництво штучних волокон значно підвищилося, особливо у зв'язку з прийнятою $€_{\text {в- }}$ росоюзом Директивою 1999/77/ЄС про заборону азбесту з 1 січня 2005 року у країнах - членах $€ C$. I все ж таки, зважаючи на потенційну небезпечність штучних волокон, Міжнародна Організація Праці (МОП) у 2000 році прийняла спеціальний Қодекс правил про безпеку при використанні синтетичних волокон (скловолокно, скельне волокно та шлаковолокно) [17], подібний Қодекс правил існує і для азбесту, тому штучні волокна можливо використовувати з тією ж самою ступеню контролю, що і азбест (WHO EHC 151). Необхідно зазначити, що азбест сьогодні є найліпше дослідженим, «передбачуваним» матеріалом, існує велика кількість експериментальних досліджень, і, що дуже важливо, епідеміологічних, вивчення ж біологічних властивостей штучних мінеральних волокон ще й досі триває. У теперішній час нараховується більше 70 різновидів штучних мінеральних волокон [8]. На ринку послуг штучні волокна пропонуються як альтернативи або прямої заміни азбесту у зв'язку з наявністю численних даних щодо агресивного впливу азбесту на працюючі контингенти, особливо азбесту амфіболової групи. Передусім це стосується країн Західної та Центральної Європи, де рівень професійних онкологічних захворю- вань $€$ досить високим та основним канцерогеном вважається азбест [1]. 3 економічних міркувань часто замовчується, що всі ці «епідемії» пов'язані головним чином з неконтрольованим використанням азбестів амфіболової групи, що є сьогодні забороненими в усьому світі.

Термін «штучні мінеральні волокна» (ШМВ) використовують для визначення аморфних, прозорих волокон, що виготовляються з розплавленого шлаку, скельної породи, скла, каоліну, сплавів кремнію 3 окислами алюмінію. Основними виробниками ШМВ є США та Європа. У Північній Америці іноді використовують термін «штучне склоподібне волокно» [2].

За комерційним принципом ШМВ можна розділити на наступні типи:

1. Безперервні волокна

2. Ізоляційні волокна (скельні волокна, шлаковолокна, скловолокна)

3. Вогнетривкі (керамічні волокна)

4. Волокна спеціального призначення

Пізніше штучні волокна були розділені на дві групи:

1. Штучні скляні волокна, що включають до своєї групи скловолокна (що представлені головним чином безперервними волокнами, волокнами спеціального призначення та мікроволокнами; ці волокна звичайно містять окисли кремнію, кальцію, натрію, калію, алюмінію та бору), мінеральні волокна, що включають скловолокна, скельні волокна та шлаковолокна. Головні складаючі скельних волокон та шлаковолокон 
- це окисли кремнію, кальцію, магнію, алюмінію та заліза.

2. Вогнетривкі керамічні волокна -аморфні або частково з кристалічною структурою волокна, що виробляють 3 каоліну або окислів алюмінію, кремнію та інших оксислів металів (в тому числі окислів цирконію та ітрію). Значно рідше вогнетривкі керамічні волокна виробляють з таких сполук, як карбіди кремнію, нітриди кремнію та нітриди бору [10].

Всі сировинні матеріали для виробництва ШМВ розплавляють при температурі $1200-1500{ }^{\circ} \mathrm{C}$. Формування волокон здійснюється трьома основними способами:

1. Механічне протягування ниток розплавленого матеріалу

2. Видування крапель, ниток у струмені полум'я, пару або повітря

3. Формування та витягування рідких розплавів.

Перераховані методи нерідко комбінуються один з одним, окремі допоміжні операції включають також витримування матеріалів у вогні, зволоження та додавання протигрибкових речовин у технологічний процес. Для зміни фізичних та хімічних властивостей у волокна можуть додаватися стабілізатори та модифікатори [2, 18].

Сучасне виробництво ізоляційної вати, вати зі скельних порід, скловати та шлаковати складає 80 \% від виробництва всіх ШМВ. Вироби з цих волокон використовуються як вогнетривкі матеріали, для звуко- та термоізоляції, при виробництві вентиляційних труб. Безперервні скляні волокна складають 10-15\% від всього виробництва ШМВ, та знайшли широке використання як сировина для армування цементу, пластика, полімерів, електричної ізоляції, при виготовленні паперу та виробів з каучуку, у текстильній промисловості. Вогнетривкі керамічні волокна складають тільки 1-2\% від виробництва всіх ШМВ та використовуються як вогнетривкі ізоляційні матеріали при виготовленні різного типа печей. Скляні волокна спеціального призначення складають менше 1 \% виробництва ШМВ, використовуються для високоефективної термічної та звукової ізоляції в авіаційно-космічній промисловості, при виготовленні акумуляторних батарей [8].

У 1972 році вперше були опубліковані докази того, що ШМВ можуть бути небезпечні для здоров'я людини $[37,45]$. У теперішній час доведено, що професійний вплив штучних волокон може зумовити виникнення плевральних бляшок, дифузних плевральних потовщень, легеневого фіброзу, раку легень, мезотеліоми плеври та очеревини $[9,20$, $24,31,39]$.Основними детермінантами токсичного впливу волокон вважаються іх розмір, стійкість, доза, біоперсистенція та інші фізико-хімічні характеристики [21, 24, 29, 44, 45, 48, ]. Біоперсистенція волокон визначається як здатність залишатися у тканинах організму з урахуванням їх кількості, розмірів, хімічних властивостей поверхні, хімічного складу, площі поверхні та інших фізичних характеристик [15, 30, 34].

ШМВ за своєю структурою аморфні, вони не розщеплюються за довжиною на волоконця меншого діаметру, але можуть ламатися поперек на більш короткі сегменти $[2,24]$. Ця властивість зумовлює швидкість очищення від цих волокон легень та $є$ основною відмінністю між азбестовими та неазбестовими волокнами. Доведено, що довгі волокна зазвичай, мають більшу біологічну активність, тому відповідно більш агресивні ніж короткі волокна, саме тому деякі автори наголошують на необхідності подальших експериментів з різними дозами $[32,46]$. Волокна довжиною 8 мкм та діаметром 0,25 мкм мають найбільший канцерогенний потенціал [19, 33, 36].

Номінальний діаметр штучних мінеральних волокон складає 6-15 мкм (безперервні волокна), 2-9 мкм (скельні волокна, шлаковолокна, скловолокна), 1,2-3,5 мкм (вогнетривкі волокна, включаючи керамічні волокна) та 0,1-3 мкм (волокна спеціального призначення). Виходячи з вище зазначеного, можна припустити: так само як безперервні скляні волокна мають великий розмір, вони мають найменший канцерогенний потенціал, а скловолокна спеціального призначення та вогнетривкі керамічні волокна -найбільший, але при цьому треба враховувати такий важливий чинник, як стійкість волокон. Це припущення підтверджують також експериментальні та епідеміологічні дослідження, хоча деякі з них досить суперечливі та обмежені. Так, вивчення розчинності та кліренсу ШМВ на легенях тварин демонструє, що скловолокна більш розчинні ніж скельні волокна, тоді як вогнетривкі керамічні волокна найбільш стійкі з усіх ШМВ та викликають більшу проліферацію мезотеліальних клітин [22, 40]. Керамічні волокна, скельні та шлаковолокна виявляють також високу канцерогенність при введенні у плевральну та перитонеальну порожнини $[9,39]$, в той самий час тривале інгаляційне введення гризунам штучних волокон дало суперечливі результати щодо виникнення ле- 
геневого фіброзу та раку, при цьому підвищення кількості пухлин не спостерігалося в інгаляційному експерименті на тваринах, але пухлини виникали після внутрішньоочеревних введень. Дослідження впливу безперервних волокон на тваринах обмеженими [44].

В інгаляційних експериментах на тваринах доведено, що керамічні вогнетривкі волокна викликають пухлини та мезотеліому $[7,28,38]$. Це також підтверджено при інтратрахеальному, інтраплевральному та інтраперитонеальному введеннях тваринам. Для керамічних вогнетривких волокон визначено одиницю (поріг) канцерогенного ризику для пухлин легень що засновано на інгаляційних експериментах на тваринах $-1 \cdot 10^{-6}$ в/л (для волокон довжиною більше 5 мкм, співвідношенням довжина / діаметр 3:1, що можливо побачити в оптичний мікроскоп) [13]. Відомо, що пухлини у тварин виникають при введенні дози, що максимально переноситься, а для людини достатньо тривалої експозиції невеликих рівнів, тому важко поки що передбачити, які наслідки треба очікувати від професійного впливу цих матеріалів.

Проведені порівняльні дослідження біоперсистенції ШМВ порівняно з азбестовими мінералами свідчать, що штучні волокна більш повільно виводяться 3 організму ніж азбест: період напіврозпаду вогнетривкого керамічного волокна (RCF1) складає 60 днів [4], скловолокна (MMVF 10) - 39 днів [11], скельного волокна (MMVF 21) - 46 днів [11], хризотилового азбесту -11 днів [5].
У проведених двох масштабних епідеміологічних дослідженнях був виявленим надлишковий ризик виникнення раку легень у робітників, які працюють зі скельними волокнами та шлаковатою, але не було виявлено такого ризику у робітників, які контактують зі скляними волокнами, скляними мікроволокнами або безперервними волокнами [43]. Також не спостерігалося підвищеної кількості випадків захворювання мезотеліомою плеври $[27,43]$. При дослідженні смертності від злоякісних пухлин на заводі з виробництва скловати у Великій Британії знайдено граничний підвищений ризик від раку легень серед цих робітників, але цей надлишковий ризик мав слабку залежність між професійним стажем та рівнем експозиції до ШСВ [12]. Shannon et al. [41] знайшли знижений ризик у робітників, які контактують зі скляними волокнами. Пізніше результати цього дослідження були підтверджені на робітниках Онтаріо [42]. Деякі автори взагалі вважають, що ШМВ не представляють значного ризику для здоров'я людини, а азбест $€$ застарілим та неконкурентноздатним матеріалом $[6,16,23,26,35,47]$.

Провідним шкідливим виробничим чинником при виготовленні штучних волокон $є$ пил, для якого встановлені рівні впливу (таблиця).

Як видно з таблиці, існуючі рівні впливу відрізняються між собою за значенням та затверджені відносно недавно (латентний період онкологічних захворювань від впливу пилу ШМВ складає від 15-20 років) тому ї надійність є суперечливим пи-

Рівні професійного впливу штучних мінеральних волокон, встановлені різними комітетами [14]

\begin{tabular}{|c|c|c|}
\hline Комітет, країна & Гранично допустима концентрація & Примітки \\
\hline $\begin{array}{l}\text { Американська Асоціація Урядових та } \\
\text { промислових гігієністів (АСGIH), } 1978\end{array}$ & $10 \mathrm{Mr} \backslash \mathrm{M} ?$ & Скляні волокна \\
\hline $\begin{array}{l}\text { Національний Інститут Професійної } \\
\text { Безпеки та Здоров'я (NIOSH), } 1977\end{array}$ & $\begin{array}{l}5 \mathrm{мг} / \mathrm{M} ? \\
3 \text { вол/мЛ }\end{array}$ & $\begin{array}{l}\text { Загальна маса скляного пилу } \\
\text { Скляні волокна (діаметр } \leq 3,5 \text { мкм, } \\
\text { довжина } \geq 10 \text { мкм) }\end{array}$ \\
\hline Німеччина, 1995 & 0,5 вол/мл & $\begin{array}{l}\text { Волокна } 3 \text { діаметром < } 3 \text { мкм, } \\
\text { довжиною }>5 \text { мкм, відношення } \\
\text { довжина /діаметр }>3: 1\end{array}$ \\
\hline Швеція, 1988 & 1 вол/мл & Синтетичні неорганічні волокна \\
\hline Велика Британія, 1992 & $\begin{array}{l}2 \text { вол/мл } \\
1 \text { вол/мл }\end{array}$ & $\begin{array}{l}\text { Штучні мінеральні волокна } \\
\text { Наддовгі волокна }\end{array}$ \\
\hline Нідерланди, 1995 & 3 вол/мл & $\begin{array}{l}\text { Респірабельні волокна (довжина } \\
\text { 5-200 мкм, діаметр<3 мкм, відношен- } \\
\text { ня довжина/діаметр не менше } 3: 1 \text { ) } \\
\end{array}$ \\
\hline Нідерланди, 1995 & 1 вол /мл & Вогнетривкі керамічні волокна \\
\hline
\end{tabular}


танням, результати подальших епідеміологічних досліджень зможуть підтвердити або спростувати ї онконебезпезпечність. Це положення стосується також і встановленої в Росії ГДКдля штучних мінеральних волокон, що складає 4 мг/м³ (середньозмінна концентрація), причому величина максимальної концентрації не визначена (Гигиеническая оценка и экспертиза материалов и товаров, содержащих природные и искусственные минеральные волокна, МУ 1.2.1796-03). Необхідно також враховувати, що при виготовленні ШМВ утворюються також волокна з меншими розмірними характеристиками, які теж реалізують свій негативний вплив на легеневу тканину. Що стосується нових комерційних типів ШМВ, вони повинні пройти детальні гігієнічні дослідження, перш ніж будуть впроваджені у виробництво.

Згідно з новою класифікацією МАВР [25] скловолокна спеціального призначення, вогнетривкі керамічні волокна належать до групи 2 В (можливі канцерогени для людини, тобто для цих речовин є обмежені докази канцерогенності для людини, немає достатніх доказів, отриманих в експериментах на тваринах), а ізоляційна скловата, безперервні скляні волокна, вата зі скельних порід та шлаковата перенесені з групи 2В до групи 3 (речовина не класифікується як канцероген). За класифікацією Директиви ЄС 97/69/ ЕС, мінеральна вата та штучні скляні волокна (силікати) з невпорядкованою організацією, що містять не більше $18 \%$ від своєї ваги $\left(\mathrm{Na}_{2} \mathrm{O}+\mathrm{K}_{2} \mathrm{O}+\mathrm{CaO}+\mathrm{MgO}+\mathrm{BaO}\right)$, класифіковані як $\mathrm{X}_{\mathrm{i}}$ «подразник», R 38 «подразнюючі шкіру». Речовина розглядається як R38, якщо:

1.При значному контакті зі шкірою тварин до 4 годин, викликає значне запалення, що триває 24 години чи більше після закінчення експозиції.

2.Практичний експеримент демонструє, що речовина здатна викликати запалення у достатньої кількості людей.

Тоді як ізоляційна вата (скловата, шлаковата, вата зі скельних порід) належать до категорії 3 , $\mathrm{R} 40$, тобто $є$ «ймовірний ризик незворотного впливу». Причому підгрунтям для віднесення речовини до категорії 3 (категорія 3 - речовини можуть мати ймовірні канцерогенні властивості, але недостатньо різноманітної інформації для їх достатньої оцінки) є результати отримані переважно на експериментальних тваринах.

За класифікацію ACGIH ізоляційна вата (скловата, шлаковата, вата зі скельних порід) належать до категорії 3 , тобто речовина канцерогенна для експериментальних тварин у відповідній високій дозі, епідеміологічні дослідження не підтверджують надлишкового ризику раку у людей [3]. Як видно, зазначені класифікації штучних мінеральних волокон дещо відрізняються між собою, а підгрунтя для віднесення деяких типів волокон до тієї чи іншої групи іноді обмежені. Беручи до уваги цей факт та зважаючи на велику різноманітність існуючих ШМВ, вивчення іх токсикологічних властивостей потребує подальших досліджень окремо для кожного типу волокон з урахуванням їх фізико-хімічних властивостей та розробки більш досконалої класифікації.

Незважаючи на те, що сучасний етап виробництва ШМВ характеризується все більшою модернізацією виробництва, включаючи використання пилоприглушуючих речовин (мінеральні олії) та полімерзв'язуючих речовин, зі значним зниженням рівнів респірабельного пилу [43], для перевірки безпечності рівнів професійного впливу необхідно визначення порогів шкідливого впливу для всіх нових ШМВ. Наявний ризик виникнення онкологічних захворювань від професійного впливу вже існуючих ШМВ потребує адекватних протипилових заходів, моніторингу рівнів експозиції та пильного нагляду за станом здоров'я працюючих, тим більше змушує відноситися з предосторогою до впровадження у виробництво нових типів ШМВ.

\section{Висновки}

1. ШМВ є потенційно небезпечними для здоров'я людини, що підтверджено проведеними експериментальними та епідеміологічними дослідженнями.

2. Основними чинниками, від яких залежить біологічна дія ШМВ є їх розмір, стійкість, доза, біоперсистенція.

3. Найбільш агресивними $є$ скловолокна спеціального призначення та вогнетривкі керамічні волокна, менш агресивні скельні волокна, шлаковолокна та скловолокна, найменш шкідливими вважаються безперервні скляні волокна.

4. Обмеженість та суперечливість результатів досліджень, а також велика різноманітність ШМВ потребує їх класифікації залежно від фізико-хімічних властивостей та визначення порогів шкідливого впливу з метою обгрунтування безпечності для здоров'я працюючих існуючих ГДК. 


\section{Лiтература}

1. Кундієв Ю.І., Нагорна А.М. Професійне здоров'я в Україні. Епідеміологічний аналіз.- К.: Авіцена, 2006.-316 c.

2. Биологическое действие искусственных минеральных волокон: Отчет о совещании ВОЗ/МАИР, Копенгаген, 20-22 апр. 1982 г.- Копенгаген, 1987.$198 \mathrm{c}$.

3. American Conference of Governmental Industrial Hygienists. Threshold Limit Values for Chemical Substances and Physical Agents and Biological Exposure Indices/ACGIH.-Cincinnati, USA, 1997.- 33 p.

4. Bellmann B., Creutzenberg O., Dasenbrock C., Ernst H., Pohlmann G., Muhle H. Inhalation tolerance study for $\mathrm{p}$-aramid respirable fiber-shaped particulates (RFP) in rats //Toxicol. Sci.- 2000.- V.54, №1.- P. 237-250.

5. Bernstein D.M., Rogers R., Smith P. The biopersistence of Canadian chrysotile asbestos following inhalation // Inhal. Toxicol.-2003.-V.15, № 3.-P.1247-1274.

6. Camstrup O. et al. The biopersistence and pathogenicity of man-made vitreous fibres after short- and long-term inhalation // Ann.Occup.Hyg.- 1998.- V.42, № 3.- P.191-199.

7. Davis J.M.G. et al. The pathogenicity of long versus short fibre sample of amosite asbestos administered to rats by inhalation and intraperitoneal injection // British J: of experimental pathology.- 1986.- № 67.- P. $415-430$.

8. De Vuyst P., Dumortier P., Swain C.M.H., Pairon J. C., Brochard P. Respiratory health effects of man-made vitreous ( mineral) fibers // Eur. Respir. J.- 1995.- № 8.- P. 214-217.

9. Ellouk S.A., Jaurand M.C. Review on animal in vivo data on biological effects of man-made fibers // Environ. Health. Perspect.- 1994.- Vol.102.- Suppl. 2.P.47-61.

10. Foa V., Basilico S. Chemical and physical characteristics and toxicology of man-made mineral fibers // Med. Lav.- 1999.- V. 90, № 1.- P. 10-52.

11. Fraunhover Institute (1998) Report.- Hannover, 1998.- 75 P.

12. Gardner M.J., Winter P.D., Pannett B., Simpson M.J., Hamilton C.,Acheson E.D. Mortality study of workers in the man-made mineral fiber production industry in the United Kingdom // Scand. J. Work Environ. Health.- 1986.- Vol. 12,Suppl. 1.- P.85-93.

13. Health-based tolerable intakes/concentrations and tumorigenic doses/concentrations for priority substances.- Ottawa, Health Canada, 1996.- 22 P.

14. Helmut A. Greim, Kyriakoula Ziegler-Skylakakis. Strategies for Setting Occupational Exposure Limits for Particles //Env. Health Perspectives.- 1997.- Vol.105.Suppl. 5.- P.1357-1361.
Hesterberg T.W. et al. Biopersistence of synthetic vitreous fibers and amosite asbestos in the rat lung following inhalation // Toxicol. Appl. Pharmacol.- 1998.Vol. 151, № 2.- P.265-275.

15. Hodson A. Industrial fibres: A technical and commercial review // Ann.Occup.Hyg.- 1993.- № 37.P. 203-210.

16. International Labour Office. Code of Practice on safety in the use of synthetic vitreous fibre insulation wools (glasswool, rockwool, slagwool).- Geneva, 2000.$35 \mathrm{p}$.

17. Klingholz R. Technology and production of manmade mineral fibers // Ann. Occup. Hyg.- 1977.№ 20.- P. 153- 159 .

18. Lee K.P. et al.// Amer J. Path.- 1981.- V.102.P.314-323.

19. Lippman M. Effects of fiber characteristics on lung deposition, retention and disease // Environ. Health. Perspect.- 1990.- № 88.- P.311-317.

20. Lippman M. Man-made mineral fibers (mmmf): human exposures and health risk assessment // Toxicol. Ind. Health.- 1990.- № 6.- P. 225-246.

21. Lockey J.E., Wiese N.K. Man-made vitreous fibers, vermiculite, and zeolite. In: Environmental and Occupational Medicine, 3rd ed ( Rom WN, ed).Philadelphia: Lippincott-Raven, 1998.- P.397-411.

22. Lohrer W. Asbest- Ersatstoffe // Staub. Reinhalt. Luft .- 1989.- № 49.- P. 61-66.

23. Man-made Mineral Fibres,WHO, Environmental Health Criteria № 77.- Geneva, 1988.- 105 P.

24. Man-made Vitreous Fibres Vol: 81 (2002), WHO, IARC Monographs on the Evaluation of Carcinogenic Risks to Humans.- 11 P.

25. Man-made mineral fibres and radon International Agency for research on cancer, IARC Monographs.-Lyon, 1988.- V.43.- P.9.

26. Marsh G. et al. Mortality among a cohort of US man-made mineral fibre workers :1985 follow-up // J. of occupational med.- 1990.- № 32.- P. 594-604.

27. Mast R.W. et al. A multiple dose chronic inhalation toxicity study of kaolin refractory

ceramic fibre (RFC) in male Fischer 344 rats // Toxicologist.- 1993.- № 13.- P. 43.

28. Maxim L.D., Hadley J.G., Potter R.M., Niebo R. The role of fiber durability / biopersistence of silicabased synthetic vitreous fibers and their influence on toxicology // Regul.Toxicol. Pharmacol.- 2006.- V.46, № 1.- P. 42-62.

29. McClellem R.O., Hesterberg T.W. Role of biopersistence in the pathogenicity of man-made fibers and methods for evaluating biopersistence- a summary of two round-tables//Biopersistence of Respirable Synthetic Fibers and Minerals // Environ. Health. Perspect.- 1994.- Vol.102. Suppl. 5.- P.277-283. 
30. Merchant J.A. Human epidemiology : a review of fiber type and characteristics in the development of malignant and non-malignant disease // Environ. Health. Perspect.- 1990.- № 88.- P.287-293.

31. Miller B.G., Searl A. et al. Influence of fibre length, dissolution and biopersistence on the production of mesothelioma in the rat peritoneal cavity / / Ann. Occup. Hyg.- 1999.- V.43, № 3.- P. 155-166.

32. Morgan A., Holmis A. // Brit.J. Industr. Med .1980.- Vol.37.- P. 25-32.

33. Muhle H., Bellman B. Biopersistence of manmade vitreous fibers // Ann. Occup. Hyg.- 1995.№ 39.- P. 655-660.

34. Plato Nils, Gustavsson Per, Krantz Staffan. Assessment of past exposure to man-made vitreous fibers in the Swedish prefabricated house industry // Amer. J. Ind. Med.- 1997.- V.32, № 4.- P.349-345.

35. Pooley A.D. Clarc W.G.// Biologicall Effects of Mineral Fibres.-Lyon., 1980.- P.79-81.

36. Pott F., Friedrichs K.N. Tumors in rat following intraperitoneal injections of fibrous dust. //Naturwissenschaften .- 1972.- V.59, № 7.- 318 P.

37. Pott F., Roller M. Carcinogenicity of synthetic fibres in experimental animals: its

significance for workers // Journal of occupational health and safety -1996.- № 12.- P. 333-339.

38. Roller M., Pott F., Kamino K. et al. Results of current intraperitoneal carcinogenicity studies with mineral and vitreous fibres // Exp. Toxicol. Pathol.- 1996.V.48, № 1.- P.3-12.

39. Rutten A.A., Bermudes E., Mangum J.B. et al. Mesothelial cell proliferation iduced by intrapleural instillation of man-made fibers in rats and hamsters // Fundam. Appl. Toxicol.- 1994.- V.23, №1.- P.107-1 16.

40. Shannon H.S., Hayes M., Julian J.A., Muir D.C. Mortality experience of glass fiber workers // Br. J. Ind. Med.- 1984.- № 41.- P.35-38.
42. Shannon H.S., Jamieson E., Julian J.A., Muir D.C.F. Mortality of glass filament (textile) workers // Br. J. Ind. Med.- 1990.- № 47.- P.533-536.

43. Simonato L., Fletcher A.C., Cherrie J.W., Anderson A., Bertazzi P. The International Agency for Research on Cancer Historical cohort study of MMMF production workers in seven European countries: extension of the follow-up / / Ann. Occup. Hyg.- 1987.№ 31.-P. 603-623.

44. Smith D.M., Ortiz L.W., Archuleta R.F., Johnson N.F. Long-term health effects in hamsters and ratsexposed chronically to man-made vitreous fibers // Ann. Occu p. Hyg.- 1987.- № 31.- P.731-754.

45. Stanton M.F. Some etiological considerations of fiber carcinogenesis //Biological Effects of Asbestos/ Eds.: Bogovski P., Gilson J., Timbrell V., WagnerJ.C.; IARC Sci. Publ. 8.- Lyon, 1973.- P. 289-294.

44. Stanton M.F.\& Layard M. The carcinogenecity of Fibrous minerals //Workshop on asbestos, definition and measurment methods ( NBS Special Publication 506 ) / Eds: Gravatt C.C., LaFleur P.D. and Heinreich K.F. J.- Washington D.C., National Measurments Laboratory ,-1978.- P.143-151.

45. Stanton M.F., Wronch C. Mechanisms of mesothelioma induction with asbestos and fibrous glass // J. of the Nat. Cancer Inst.- 1972.- № 48.P.797-821.

46.Towards an understanding of the carcinogenecity of fibrous materials. Sensible Manag. Natur. Resonr.Asbestos Inst. 1993.- P.1,4-5.

47. Virta R. Asbestos substitutes matching performance //Ind. Minerals.- 1992.- № 303.- P. 47-51.

48. Wright G.W., Kuschner M. (1977). The influence of varying lengths of glass and asbestos fibers on tissue response in guinea pigs// Inhaled Particles IV/ Ed WH Walton. Pergamon Press,- Oxford ; New York, 1977.P.455-474.

\section{Пятница-Горпинченко Н.К. \\ ОПАСНЫ АИ ИСКУССТВЕННЫЕ ЗАМЕНИТЕАИ АСБЕСТА? (О6зор митературы)}

\section{Институт медишины труда АМН Украины, Киев}

Стремительное развитие современных технологий производства приводит к возникновению качественно новых видов продукции, включая также искусственные минеральные волокна с заданными свойствами. Доказано, что воздействие искусственных минеральных волокон может обусловить возникновение таких заболеваний, как плевральные бляшки, диффузные плевральные утолщения, фиброз легких, рак легких, мезотелиома плевры и брюшины. Необходимо констатировать, что существующие результаты экспериментальных и эпидемиологических исследований не позволяют сделать окончательный вывод о полной безопасности искусственных минеральных волокон для здоровья человека, многие вопросы остаются спорными и нерешенными, такие как: классификация искусственных минеральных волокон в зависимости от физико-химических свойств, определение порогов вредного воздействия, поэтому дальнейшее изучение биологического действия искусственных минеральных волокон и их вклада в развитие профессиональной патологии является одной из актуальных проблем сегодняшнего дня.

Ключевые слова: искусственные минеральные волокна, асбест, биоперсистенция, уровни профессионального воздействия, порог вредного воздействия 


\section{Piatnytsia-Gorpynchenko N.IK.}

\section{ARE ARTIFICIAL SUBSTITUTES OF ASBESTOS HAZARDOUS?} (Review of literature)

Institute for Occupational Health of AMS of Ukraine, Kiev

Progressive technology induces qualitatively new types of production, including man-made mineral fibers with specified characteristics.

It has proved that the exposure to man-made mineral fibres can cause pleural plaque, diffuse pleural thickening, lung fibrosis, lung cancer, pleural and abdominal methotheliomas.

It is established that results of experimental and epidemiological investigations do not allow to conclude that man-made mineral fibres are safe for human health.

Many problems concerning classification of man-made mineral fibres depending on their physical and chemical characteristics and determination of threshold limit values haven't yet solved. It is a current problem to investigate the biological effect of man-made artificial fibres and their contribution to development of occupational pathology.

Key words: man-made mineral fibres, asbestos, biopersistence, occupational exposure levels, threshold limit values

Надійшла: 07.05.2007

Контактна особа: П'ятниця-Горпинченко Н.К., аспірант, Інститут медицини праці АМН України, вул. Саксаганського, 75, Київ 01033, Україна; тел. (044) 289-43-66 